\title{
BEDA PENGARUH INTERVENSI PEREGANGAN DAN MOBILISASI SENDI TERHADAP PERBAIKAN KETERBATASAN LINGKUP GERAK SENDI
}

\author{
Bambang Trisnowiyanto \\ Jurusan Fisioterapi Politeknik Kesehatan Kemenkes.R.I. Surakarta \\ Email: trisnowiyanto@yahoo.co.id
}

\begin{abstract}
Abstrack: The Difference of Stretching and Joint Mobilization Intervention Effect to Improved Range of Motion (ROM). Limited range of motion is a term meaning that a joint or body part cannot move through its normal range of motion. Limited range of motion can interfere with daily activities. These study purposes were to determine differences in the intervention effect of stretching techniques to reduce limited range of motion. Two techniques were used that techniques of end range mobilization and mobilization with movement towards. Study subjects were 20 patients aged 40-50 years with frozen shoulder. Methods of experimental research with two group pre and post test design. Post-test was used to test differences between before and after treatment. In the mobilization with movement group, post test results showed mean differences of pre and post ROM value in the external shoulder rotation, shoulder abduction and internal shoulder rotation were $19,5^{\circ} ; 31,5^{\circ}$ and $27^{\circ}$, respectively. The end range mobilization group, post test results showed mean differences of pre and post ROM value in the external shoulder rotation, shoulder abduction and internal shoulder rotation were $5,5^{\circ} ; 11,5^{\circ}$ and $7,5^{\circ}$, respectively. Thus concluded that mobilization with movement technique is more influential than end range mobilization technique to improved range of motion.
\end{abstract}

Keywords: Mobilization with movement, End range mobilization, Range of motion (ROM)

\begin{abstract}
Abstrak: Beda Pengaruh Intervensi Peregangan dan Mobilisasi Sendi terhadap Perbaikan Keterbatasan Lingkup Gerak Sendi. Keterbatasan sendi adalah hilangnya kemampuan mobilitas aktif dan pasif dari suatu persendian tubuh yang mengakibatkan terganggunya aktivitas kegiatan sehari-hari. Tujuan dilakukan penelitian ini adalah untuk mengetahui perbedaan pengaruh intervensi peregangan sendi dengan teknik end range mobilization dan mobilization with movement terhadap perbaikan keterbatasan lingkup gerak sendi dengan subjek penelitian 20 orang pasien frozen shoulder dengan rentang usia 40-65tahun. Metode penelitian yang digunakan adalah experimental, dengan rancangan two group pre and post test design. Hasil uji beda post test kelompok mobilization with movement diperoleh hasil selisih rerata nilai LGS pre dan post, untuk LGS eksternal rotasi bahu adalah 19,5 $5^{\circ}$, untuk LGS abduksi bahu adalah $31,5^{\circ}$, dan LGS internal rotasi bahu adalah $27^{\circ}$. Sedangkan hasil selisih rerata pada kelompok end range mobilization untuk LGS eksternal rotasi bahu adalah 5,5 $5^{\circ}$ untuk LGS abduksi bahu adalah $11,5^{\circ}$ dan untuk LGS internal rotasi bahu adalah $7,5^{\circ}$. Maka dapat disimpulkan intervensi teknik mobilization with movement lebih berpengaruh dibandingkan teknik peregangan dengan end range mobilization terhadap perbaikan keterbatasan lingkup gerak sendi.
\end{abstract}

Kata kunci: Mobilization with movement, End range mobilization, Lingkup gerak sendi

Lingkup gerak sendi adalah kemampuan gerak persendian tubuh untuk dapat melakukan kegiatan sehari-hari. Gerak sendi merupakan suatu mekanisme hubungan tulang yang digerakkan oleh otot ataupun gaya eksternal lain dalam lingkup geraknya. Ketika sendi bergerak dalam lingkup tertentu maka semua struktur yang berada di sekitar persendian akan ikut terpengaruh diantaranya otot, permukaan sendi, kapsul sendi, ligamen, fascia, pembuluh darah dan saraf. Lingkup gerak sendi (LGS) merupakan dasar untuk mengidentifikasi fisiologis dari suatu hubungan tulang yang dapat bergerak dan hasilnya dapat digunakan sebagai dasar indikatif pemberian intervensi terapeutik tertentu. Untuk mempertahankan kemampuan LGS, setiap sendi harus memiliki lingkup gerak (Kisner, 2007). LGS terbagi menjadi lingkup gerak sendi aktif dan pasif. LGS aktif adalah kemampuan sendi untuk bergerak akibat adanya kontraksi otot secara aktif dan tanpa bantuan dari luar individu, sedang LGS pasif adalah kemampuan sendi untuk dapat digerakan tanpa adanya kontraksi otot dari individu tersebut atau akibat adanya 
bantuan dari luar. Kisaran LGS yang mampu dilakukan diukur dengan goneometer yang dicatat dalam skala derajat menurut standar ISOM (International Standart Orthopaedic Measurements), adapun pengukuran LGS diproyeksikan berdasarkan posisi anatomis tubuh manusia dan bidang gerak yang terdiri dari: (1) bidang gerak sagital, gerak yang diukur adalah gerak fleksi-ekstensi, (2) bidang gerak frontal, gerak yang diukur adalah gerak abduksi-adduksi, (3) bidang gerak horizontal, gerak yang diukur adalah gerak rotasi. Sedang sendi yang komplek memiliki semua bidang gerak akan terjadi pada sendi gluboidea atau ball and socket joint, yaitu pada sendi panggul dan sendi bahu. Pada penelitian ini akan dibahas metode penambahan LGS bahu atau articulatio glenohumeral yang mengalami keterbatasan atau dikenal dengan bahu beku atau frozen shoulder. Istilah frozen shoulder pertama kali digunakan oleh Codman pada tahun 1934 untuk menggambarkan kondisi tendinitis akibat spasme rotator cuffmuscle atau adanya perlengketan pada kapsul sendi atau bursa (Neviaser, 2010). Frozen shoulder adalah segala bentuk kekakuan dan nyeri yang berada di daerah bahu (Donatelli, 1997). Frozen shoulder juga disebut capsulitis adhesive atau periarthritis yang merupakan gangguan kronis pada sendi bahu dengan gejala khas berupa hilangnya LGS secara progresif akibat adanya kontraktur pada kapsul sendi. Gejala klinis ditandai dengan nyeri, keterbatasan LGS, dan penurunan kekuatan otot akibat tidak digunakan (Yang et al, 2007). Frozen shoulder terbagi menjadi dua kategori (Kisner, 2012) yaitu, primer dan sekunder. Frozen shoulder primer bersifat occurs spontaneously and unknown cause (Hinton, 2010). Frozen shoulder sekunder digunakan untuk menggambarkan kondisi kekakuan dan nyeri yang timbul sebagai akibat adanya trauma atau penyakit lain yang bersifat ekstra artikuler.

\section{Metode Peregangan dan Mobilisasi Sendi}

Metode recovery untuk penambahan LGS secara manual yang dikenalkan oleh Maitland sejak tahun 1983, adalah metode mobilisasi sendi yang terdiri dari: (1) teknik peregangan sendi atau end range mobilization (ERM), dan (2) teknik gerak rolling dan gliding pada persendian atau mobilization with movement (MWM), (Kumar, 2012).

Mobilisasi sendi ERM adalah metode gerakan pasif yang terdiri dari: (1) gerak pasif oscilasi dengan 2-3 repetisi perdetik, (2) gerak pasif stretching disertai osilasi. Osilasi adalah gerakan pasif pada sendi dengan amplitudo besar atau kecil yang dilakukan ketika permukaan sendi dalam keadaan distraksi dan kompresi. Gerak osilasi dapat berupa gerak arthrokinematika atau osteokinematika. Grade osilasi terdiri dari: (1) grade I yaitu amplitudo kecil, dilakukan pada awal lingkup gerak dan oscilasi dilakukan dengan cepat seperti vibrasi, (2) grade II yaitu amplitudo besar, dilakukan pada rentang gerak tetapi tidak mencapai batas lingkup gerak sendi dan dilakuan oscilasi 2-3 kali perdetik selama 1-2 menit, (3) grade III yaitu amplitudo besar, dilakukan sampai batas lingkup gerak sendi dan oscilasi 2-3 kali perdetik selama 1-2 menit, (4) grade IV yaitu amplitudo kecil, dilakukan pada akhir batas lingkup gerak. Teknik ERM dengan oscilasi yang ritmis akan merangsang mekanoreseptor tipe 2 dan menghinhibisi nosiseptor tipe 4, sehingga dapat memblokir nociceptive pathways di tingkat spinal dan batang otak, sehingga nyeri tidak dipersepsikan. Berkurangnya nyeri dapat memudahkan pasien menggerakkan sendi bahunya (Kumar, 2012). Prinsip dasar teknik ERM adalah meregangkan jaringan periartikuler di sekitar sendi yang memendek sehingga dapat mengembalikan joint-play sendi. Peregangan pada jaringan periartikuler menyebabkan adanya remodeling pada jaringan periartikuler melalui pelepasan abnormal cross-link antar serabut kolagen dan akan menstimulasi respon jaringan kolagen untuk meningkatkan daya tensilestrenght melalui sintesis kolagen dan komponen ekstraseluler lainnya. Jaringan kolagen yang berada pada posisi tidak teratur (cross-link) dirubah posisinya menjadi lurus kembali sesuai dengan arah ketegangan yang diterima. Hal ini dapat memulihkan jaringan kolagen kembali normal dan dapat memelihara ekstensibilitas jaringan periartikuler di sekitar sendi serta menjaga mobilitas sendi (Mueller and Maluf, 2002). Aplikasi teknik ERM untuk menambah LGS bahu dengan osilasi 3 kali perdetik, sebanyak 10-15 kali repetisi, 3 set persesi terapi dan waktu istirahat 30 detik antar set. Intervensi ERM dilakukan 3 kali perminggu selama 3 minggu.

Teknik $M W M$ adalah teknik manual terapi yang digunakan untuk menejemen nyeri pada kondisi hipomobility sendi (Teys, 2006). Teknik ini merupakan kombinasi dari gerak rolling dan gliding pada caput humeri yang merupakan bagian dari gerak artrokinematik dan osteokinematik yang dilakukan secara aktif maupun pasif sampai batas actual position sendi yang bersangkutan (Yang et al, 2007). Aplikasi $M W M$ mengikuti hukum konkaf dan konvek, jika 
permukaan sendi konkaf bergerak terhadap permukaan sendi konvek maka gerakan gliding akan searah dengan gerakan tulang, sedangkan bila permukaan sendi konvek bergerak terhadap permukaan sendi konkaf maka arah gliding akan berlawanan arah dengan gerakan tulang (Kaltenborn, 2001). Gerak gliding caput humeri $(\mathrm{GCH})$ yang disertai roll-gliding baik secara pasif atau aktif akan menyebabkan otot dan jaringan di sekitar sendi yang memendek menjadi terulur. Hal ini akan merangsang propioseptor pertama yaitu muscle spindle $(M S)$ dan propioseptor kedua yaitu golgi tendon organ (GTO). MS merupakan serabut yang sensitif terhadap perubahan panjang otot dan berfungsi memonitor kecepatan dan durasi penguluran. Sedangkan GTO sensitif terhadap ketegangan otot dan jaringan lunak di sekitar sendi. Gliding yang dipertahankan selama 10 detik akan menyebabkan otot dan jaringan lunak di sekitar sendi yang memendek akan terulur. Pada saat otot terulur $M S$ juga terulur. $M S$ akan melaporkan perubahan panjang otot dan seberapa cepat perubahan panjang itu terjadi serta memberikan sinyal pada medula spinalis untuk meneruskan informasi ke sususnan saraf pusat (SSP) dan SSP memerintahkan untuk mempertahankan perubahan panjang otot. Pada saat yang bersamaan GTO akan terstimulasi dan menginhibisi ketegangan pada otot sehingga memberikan pemanjangan pada komponen elastik otot dan otot dapat dengan mudah dipanjangkan. Secara bertahap $M S$ dan GTO akan beradaptasi dan terlatih untuk memberikan panjang otot yang lebih besar lagi (Teys et al, 2006). Gerak $G C H$ akan memberikan dorongan pada jaringan lunak di sekitar sendi sesuai dengan arah $G C H$. Hal ini akan menyebabkan jaringan lunak yang memendek dan mengalami perlengketan menjadi teregang. Pada saat serabut otot berada pada posisi memanjang maksimum maka seluruh sarkomer akan terulur secara penuh dan memberikan dorongan pada jaringan penghubung yang ada di sekitarnya, ketika ketegangan jaringan meningkat diharapkan akan diperoleh rileksasi pada jaringan tersebut melalui pelepasan analgesik endogenus opiate (AEO) melalui descending pain control mechanisms. $A E O$ diperoleh melalui aktivasi nosiseptor $\mathrm{A} \delta$ dan $\mathrm{C}$ yang akan mentransmisikan impuls menuju periaquductal grey region yang terletak di midbrain dan akan ikut menstimulus raphe nucleus di pons dan medulla spinalis sehingga release serotonin melalui traktus dorso-lateral dan enkhepalin di interneuron. Hal ini menyebabkan inhibisi transmisi impuls menuju second-orders neurons sehingga nyeri tidak dipersepsikan (Kisner, 2012), dengan tidak dipersepsikannya nyeri, maka akan memudahkan pasien untuk menggerakkan sendi bahunya dan memudahkan terapis saat melakukan roll-gliding dan gerak pasif sehingga terjadi peningkatan lingkup gerak sendi bahu. Menurut Goyal (Vicenzino et al, 2007) saat terjadi gerakan $G C H$ akan merangsang reseptor sendi yaitu propiseptor untuk meneruskan impuls menuju serabut saraf aferen yang akan ditransmisikan menuju sistem saraf pusat sehingga posisi sendi dan gerakan sendi disadari yang disebut dengan propioceptive feedback. Hal ini akan membantu koreksi caput humeri yang mengalami subluksasi sehingga terjadi perbaikan arthrokinematika sekaligus osteokinematika sendi bahu. Aplikasi $M W M$ pada kondisi keterbatasan LGS bahu diberikan untuk memperbaiki pola kapsuler dimana gerak eksternal rotasi lebih terbatas dari gerak abduksi dan lebih terbatas dari gerak internal rotasi. Untuk menambah LGS eksternal rotasi dilakukan $G C H$ ke antero-medial, menambah LGS abduksi dilakukan $\mathrm{GCH}$ ke kaudal dan untuk meningkatkan LGS internal rotasi dilakukan $\mathrm{GCH}$ ke postero-lateral. Gerakan $\mathrm{GCH}$ dipertahankan selama 10 detik bersamaan dengan menggerakkan sendi bahu ke arah eksternal rotasi, abduksi dan internal rotasi sampai pada posisi actual position. Teknik $\mathrm{GCH}$ dilakukakan 10 kali repetisi perset sebanyak 3 sets setiap sesi intervensi, dengan waktu istirahat 30 detik antar sets. Intervensi $M W M$ diberikan 3 kali seminggu selama 3 minggu.

\section{METODE PENELITIAN}

Penelitian ini merupakan penelitian eksperimen dengan rancangan two groups pre and post test design yang bertujuan untuk membandingkan pengaruh teknik mobilization with movement dengan end range mobilization terhadap perbaikan lingkup gerak sendi bahu, dengan kriteria subjek yang telah didiagnosis oleh dokter menderita keterbatasan LGS yang telah melewati masa akut atau tidak ada tandatanda radang yang bersifat akut, dengan rentang usia usia 40-65 tahun, dapat berkomunikasi dengan baik, kooperatif dan bersedia mengikuti program penelitian. Alat ukur yang digunakan untuk menilai LGS bahu adalah goniometer dengan nilai inter-rater; $\mathrm{r}=0,9$ dan intra rater; Rho $=0,99$ (Riddle, 1987). Variabel penelitian ini adalah: (1) teknik mobilization with movement dan end range mobilization, (2) lingkup gerak sendi. 


\section{HASIL}

Karakteristik subjek penelitian berdasarkan jenis kelamin adalah sebagai berikut: total subjek penelitian sebanyak 20 orang dengan subjek lakilaki sebanyak 11 orang (55\%) dan subjek perempuan 9 orang $(45 \%)$. Jumlah subjek pada kelompok $M W M$ terdiri dari 6 orang laki-laki (60\%) dan 4 orang perempuan (40\%), sedang pada kelompok ERM terdiri dari 5 orang laki-laki (50\%) dan 5 orang perempuan $(50 \%)$.

Karakteristik subjek berdasarkan usia: kelompok $M W M$ mempunyai rata-rata usia 53,70 tahun dengan usia minimum 50 tahun dan usia maksimum 60 tahun. Variabel umur kelompok ERM mempunyai rata-rata usia 55,10 tahun dengan usia minimum 50 tahun dan usia maksimum 61 tahun.

Tabel 1. Distribusi Subjek Berdasarkan Jenis Kelamin

\begin{tabular}{|c|c|c|c|c|}
\hline \multirow{2}{*}{$\begin{array}{c}\text { Jenis } \\
\text { kelamin }\end{array}$} & \multicolumn{2}{|c|}{$\begin{array}{c}\text { Kelompok } \\
M W M\end{array}$} & \multicolumn{2}{|c|}{$\begin{array}{c}\text { Kelompok } \\
\text { ERM }\end{array}$} \\
\hline & $\mathbf{f}$ & $\%$ & $\mathbf{f}$ & $\%$ \\
\hline Laki-laki & 6 & 60 & 5 & 50 \\
\hline Perempuan & 4 & 40 & 5 & 50 \\
\hline Jumlah & 10 & 100 & 10 & 100 \\
\hline
\end{tabular}

Kondisi awal hasil pengukuran LGS subjek pada kedua kelompok penelitian adalah sebagai berikut: (1) pada kelompok $M W M$ diperoleh hasil LGS eksternal rotasi bahu minimum $45^{\circ}$ dan maksimum $60^{\circ}$ dengan rerata $49,0^{\circ}$. Hasil LGS abduksi bahu minimum $100^{\circ}$ dan maksimum $130^{\circ}$ dengan rerata $114,00^{\circ}$. hasil LGS internal rotasi bahu minimum $25^{\circ}$ dan maksimum $45^{\circ}$ dengan rerata $33,50^{\circ}$, sedangkan (2) hasil pada kelompok ERM diperoleh hasil LGS eksternal rotasi bahu minimum $40^{\circ}$ dan maksimum $60^{\circ}$ dengan rerata $48,0^{\circ}$. Hasil LGS abduksi bahu minimum $100^{\circ}$ dan maksimum $130^{\circ}$ dengan rerata $113,50^{\circ}$. Hasil LGS internal rotasi bahu minimum $15^{\circ}$ dan maksimum $50^{\circ}$ dengan rerata $39,50^{\circ}$.

Tabel 2. Karakteristik Subjek Berdasarkan Usia

\begin{tabular}{crr}
\hline & \multicolumn{1}{c}{ Kelompok } & \multicolumn{1}{c}{ Kelompok } \\
$\boldsymbol{M W M}(\mathbf{n = 1 0})$ & $\boldsymbol{E R M}(\mathbf{n = 1 0})$ \\
\hline Minimum & 50 & 50 \\
Maximum & 60 & 61 \\
Mean & 53,70 & 55,10 \\
Standar deviasi & $\pm 3,234$ & $\pm 4,358$ \\
\hline
\end{tabular}

Tabel 3. Data Hasil Pengukuran LGS Sebelum Perlakuan

\begin{tabular}{crrrrrrrrr}
\hline & \multicolumn{4}{c}{ Kelompok $\boldsymbol{M W M}$} & \multicolumn{3}{c}{ Kelompok $\boldsymbol{E R M}$} \\
\cline { 2 - 10 } Variabel LGS & Nilai min & $\begin{array}{r}\text { Nilai } \\
\text { maks }\end{array}$ & Mean & $\begin{array}{r}\text { St. } \\
\text { deviasi }\end{array}$ & Nilai min & $\begin{array}{r}\text { Nilai } \\
\text { maks }\end{array}$ & Mean & $\begin{array}{r}\text { St. } \\
\text { deviasi }\end{array}$ \\
\hline Eksorotasi & 45 & 60 & 49,00 & 6,146 & 40 & 60 & 48,00 & 5,869 \\
Abduksi & 100 & 130 & 114,00 & 8.433 & 100 & 130 & 113,50 & 9,443 \\
Endorotasi & 25 & 45 & 33,50 & 7.091 & 15 & 50 & 39,50 & 10,395 \\
\hline
\end{tabular}

Kondisi akhir subjek setelah perlakuan adalah sebagai berikut: (1) hasil pengukuran LGS bahu pada kelompok $M W M$ : hasil LGS eksternal rotasi bahu minimum $60^{\circ}$, dan maksimum $80^{\circ}$ dengan rerata $68,50^{\circ}$. Hasil LGS abduksi bahu minimum $125^{\circ}$ dan maksimum $160^{\circ}$ dengan rerata $145,50^{\circ}$. Hasil LGS internal rotasi bahu minimum $40^{\circ}$ dan maksimum $80^{\circ}$ dengan rerata $60,50^{\circ}$, (2) hasil pengukuran LGS bahu pada kelompok ERM: hasil LGS eksternal rotasi bahu minimum $45^{\circ}$ dan maksimum $65^{\circ}$ dengan rerata $53,50^{\circ}$. Hasil LGS abduksi bahu minimum $110^{\circ}$ dan maksimum $140^{\circ}$ dengan rerata $125,0^{\circ}$. Hasil LGS internal rotasi bahu minimum $25^{\circ}$ dan maksimum $65^{\circ}$ dengan rerata $47,0^{\circ}$.

Tabel 4. Data Hasil Pengukuran LGS Sesudah Perlakuan

\begin{tabular}{crrrrrrrrr}
\hline & \multicolumn{4}{c}{ Kelompok $\boldsymbol{M W M}$} & \multicolumn{3}{c}{ Kelompok $\boldsymbol{E R M}$} \\
\cline { 2 - 10 } Variabel LGS & $\begin{array}{r}\text { Nilai } \\
\text { min }\end{array}$ & $\begin{array}{c}\text { Nilai } \\
\text { maks }\end{array}$ & Mean & $\begin{array}{r}\text { St. } \\
\text { Deviasi }\end{array}$ & $\begin{array}{r}\text { Nilai } \\
\text { min }\end{array}$ & $\begin{array}{r}\text { Nilai } \\
\text { maks }\end{array}$ & Mean & $\begin{array}{r}\text { St. } \\
\text { deviasi }\end{array}$ \\
\hline Eksorotasi bahu & 60 & 80 & 68,50 & 9,144 & 45 & 65 & 53,50 & 7,472 \\
Abduksi bahu & 125 & 160 & 145,50 & 11,655 & 110 & 140 & 125,0 & 10,000 \\
Endorotasi bahu & 40 & 80 & 60,50 & 12,349 & 25 & 65 & 47,0 & 10,593 \\
\hline
\end{tabular}




\section{a. Analisis Data}

Uji homogenitas sebelum perlakuan antara kelompok $M W M$ dan ERM dengan MannWhitney test dengan $\mathrm{p}<0.05$ : (1) LGS eksternal rotasi bahu 46,000 dengan $p=0,739$ ( $p>0,05)$. LGS abduksi bahu 49,500 dengan $p=0,968$ ( $p>0,05)$. LGS internal rotasi bahu 6,500 dengan $p=0,063$ ( $\mathrm{p}>0,05)$. Hal ini menunjukkan bahwa data homogeni atau tidak ada perbedaan yang bermakna antara kedua kelompok subjek penelitian sebelum perlakuan.

Tabel 5. Uji Inter Kelompok Sebelum

\begin{tabular}{|c|c|c|c|}
\hline \multicolumn{2}{|c|}{ Perlakuan } & & \\
\hline Uji & LGS & LGS & LGS \\
\hline Analisis & $\begin{array}{c}\text { Eksorotasi } \\
\text { Bahu }\end{array}$ & $\begin{array}{c}\text { Abduksi } \\
\text { Bahu }\end{array}$ & $\begin{array}{c}\text { Endorotasi } \\
\text { Bahu }\end{array}$ \\
\hline $\begin{array}{l}\text { Mann- } \\
\text { Whitney }\end{array}$ & 46,000 & 49,500 & 26,500 \\
\hline$p$-value & 0,739 & 0,968 & 0,063 \\
\hline
\end{tabular}

Hasil uji beda sebelum dan sesudah perlakuan pada kelompok $M W M$ dengan Wilcoxon-Test untuk LGS eksternal rotasi bahu diperoleh $p=0,005(\mathrm{p}<0,05)$, LGS abduksi bahu $p=0,005(\mathrm{p}<0,05)$, dan LGS internal rotasi bahu $p=0,005(\mathrm{p}<0,05)$. Hal ini menunjukkan ada pengaruh $M W M$ terhadap perbaikan keterbatasan LGS.

Tabel 6. Hasil Uji Intra Kelompok MWM

\begin{tabular}{cccc}
\hline Probabilitas & $\begin{array}{c}\text { LGS ekso } \\
\text { pre-post } \\
\text { test }\end{array}$ & $\begin{array}{c}\text { LGS abd } \\
\text { pre-post } \\
\text { test }\end{array}$ & $\begin{array}{c}\text { LGS endo } \\
\text { pre-post } \\
\text { test }\end{array}$ \\
\hline p-value & 0,005 & 0,005 & 0,005 \\
\hline
\end{tabular}

Hasil uji beda sebelum dan sesudah perlakuan pada kelompok ERM dengan Wilcoxon-Test untuk LGS eksternal rotasi bahu $p=0,008(\mathrm{p}<0,05)$, LGS abduksi bahu $p=0,004$ $(\mathrm{p}<0,05)$ dan LGS internal rotasi bahu $p=0,007$ $(\mathrm{p}<0,05)$. Hal ini menunjukkan ada pengaruh ERM terhadap perbaikan keterbatasan LGS.

Tabel 7. Hasil Uji Intra Kelompok ERM

\begin{tabular}{cccc}
\hline Probabilitas & $\begin{array}{c}\text { LGS ekso } \\
\text { pre-post } \\
\text { test }\end{array}$ & $\begin{array}{c}\text { LGS abd } \\
\text { pre-post } \\
\text { test }\end{array}$ & $\begin{array}{c}\text { LGS endo } \\
\text { pre-post test }\end{array}$ \\
\hline$p$-value & 0,008 & 0,004 & 0,007 \\
\hline
\end{tabular}

Hasil uji Mann-Whitney setelah perlakuan untuk LGS eksternal rotasi bahu $12,000 p=0,003 \quad(p<0,05)$, LGS abduksi bahu $10,000 p=0,002(p<0,05)$, LGS internal rotasi bahu 20,000 $p=0,021 \quad(p<0,05)$. Hal ini menunjukkan ada perbedan pengaruh $M W M$ dan $E R M$ terhadap perbaikan keterbatasan LGS.

\begin{tabular}{cccc} 
Tabel 8. & $\begin{array}{c}\text { Uji } \\
\text { Perlakuan }\end{array}$ & Kelompok & Setelah \\
\hline Probabailitas & $\begin{array}{c}\text { LGS } \\
\text { eksorotasi } \\
\text { bahu pre- } \\
\text { post test }\end{array}$ & $\begin{array}{c}\text { LGS } \\
\text { abduksi } \\
\text { bahu } \\
\text { pre-post } \\
\text { test }\end{array}$ & $\begin{array}{c}\text { LGS } \\
\text { endorotasi } \\
\text { bahu pre- } \\
\text { post test }\end{array}$ \\
\hline$p$-value & 0,003 & 0,002 & 0,021 \\
\hline
\end{tabular}

Berdasarkan hasil uji beda post test kelompok $M W M$ diperoleh hasil selisih rerata nilai LGS pre dan post untuk LGS eksternal rotasi bahu adalah $19,5^{\circ}$, untuk LGS abduksi bahu adalah $31,5^{\circ}$, dan LGS internal rotasi bahu adalah $27^{\circ}$.

Sedangkan hasil selisih rerata pada kelompok ERM untuk LGS eksternal rotasi bahu adalah $5,5^{\circ}$, untuk LGS abduksi bahu adalah $11,5^{\circ}$ dan untuk LGS internal rotasi bahu adalah $7,5^{\circ}$. Hal ini menunjukkan kelompok $M W M$ memiliki nilai rerata yang lebih besar dibandingkan kelompok ERM dan dapat disimpulkan bahwa $M W M$ lebih berpengaruh dibanding ERM terhadap perbaikan keterbatasan LGS.

Tabel 9. Selisih Rerata Nilai LGS Pre dan Post Test

\begin{tabular}{ccc}
\hline \multirow{2}{*}{ Variabel LGS } & \multicolumn{2}{c}{$\begin{array}{c}\text { Selisih rerata nilai LGS pre dan } \\
\text { post test }\end{array}$} \\
\cline { 2 - 3 } & Kelompok & Kelompok \\
& MWM & ERM \\
\hline Eksorotasi bahu & 19,5 & 5,5 \\
Abduksi bahu & 31,5 & 11,5 \\
Endorotasi bahu & 27 & 7,5 \\
\hline
\end{tabular}

\section{PEMBAHASAN}

Mobilization with movement (MWM) adalah salah satu teknik manual terapi yang direkomendasikan untuk penanganan kasus musculoskeletal berupa keterbatasan gerak sendi pada tubuh. Metode ini merupakan kombinasi dari teknik gliding pada caput humeri disertai dengan gerakan osteokinematic yang dilakukan baik secara aktif maupun pasif (Kachingwe, 2008 dan Teys, 2006). Banyak penelitian yang merekomendasikan penggunaan $M W M$ sebagai salah satu intervensi yang dapat digunakan untuk perbaikanj keterbatasan gerak sendi seperti pada kasus frozen shoulder, salah satu hasil penelitian Kachingwe (2008) tentang perbedaan pengaruh terapi manual dengan terapeutic exercise pada pasien shoulder impingement dengan gejala klinis 
nyeri dan keterbatasan LGS bahu. Hasilnya kelompok $M W M$ secara statistik menunjukkan hasil lebih tinggi terhadap peningkatan active range of motion (AROM) sendi bahu, penurunan nyeri dan peningkatan kemampuan fungsional sendi bahu dibandingkan dengan kelompok yang diberikan modalitas lain.

Teknik intervensi manual terapi lain yang direkomendasikan untuk perbaikan keterbatasan LGS adalah dengan teknik end range mobilization (ERM). ERM adalah teknik peregangan passive stretching yang ditujukan untuk kapsul sendi pada seluruh bidang gerak sendi. Penelitian Vermeulen (2000) yang berjudul End-Range Mobilization Techniques in Adhesive Capsulitis of the Shoulder Joint, menunjukkan adanya peningkatan kapasitas sendi bahu dan mobilitas sendi bahu pada 7 pasien dengan capsulitis adhesive setelah 3 bulan pemberian end-range mobilization techniques dan 5 pasien dilaporkan tidak lagi merasakan nyeri pada sendi bahu yang terkena setelah 3 bulan post treatment.

Penelitian Goyal (2013), tentang pengaruh pemberian terapi kombinasi antara ERM dengan MWM untuk perbaikan keterbatasan LGS, menunjukan bahwa kombinasi terapi manual antara ERM dan MWM lebih baik dalam meningkatkan ROM sendi bahu dan SPADI scores pada pasien dengan frozen shoulder dibandingkan dengan hanya menggunakan ERM saja ataupun MWM saja.

Penelitian Yang et al (2007) yang membandingkan teknik ERM dan MWM pada kasus frozen shoulder, menunjukan hasil subjek mengalami perbaikan selama 12 minggu, tetapi perbaikan signifikan secara statistik terlihat pada kelompok end-range mobilization dan kelompok mobilization with movement techniques, selain itu perbaikan scapulo-humera lrhythm dengan mobilization with movement techniques lebih baik dibanding end-range mobilization. Penelitian Arshad et al (2013) dan penelitian Kazmi et al (2013) yang sama-sama meneliti tentang perbedaan pengaruh end range mobilization dan mobilization with movement, hasil penelitian keduanya menunjukkan bahwa end range mobilization dan mobilization with movement dapat digunakan untuk meningkatkan LGS dan menurunkan nyeri pada frozen shoulder. Tetapi kesimpulan dari kedua penelitian tersebut berbeda, pada penelitian Kazmi et al (2013) didapat bahwa mobilization with movement lebih baik dibandingkan end range mobilization dalam menurunkan nyeri, meningkatkan LGS sendi bahu dan kemampuan fungsional. Sedangkan pada penelitian Arshad et al (2013) di dapat bahwa tidak ada perbedaan pengaruh antara end range mobilization dan mobilization with movement dalam menurunkan nyeri dan meningkatkan LGS sendi bahu pada frozen shoulder.

Pada penelitian ini, intervensi teknik mobilization with movement lebih berpengaruh untuk perbaikan keterbatasan LGS dibanding end range mobilization. Hasil ini sejalan dengan penelitian Yang et al (2007), yang berjudul "mobilization techniques in subject subject with frozen shoulder syndrome: randomized multipletreatment trial", dimana kasus frozen shoulder diberikan terapi manipulasi dengan membandingkan 3 teknik mobilisasi yaitu end range mobilization (ERM), mid-range mobilization (MRM) dan mobilization with movement techniques (MWM).

\section{Implikasi Klinis}

Untuk memperbaiki keterbatasan LGS terutama pada sendi bahu dapat diberikan teknik mobilization with movement dan end range mobilization, tetapi pemberian mobilization with movement (MWM) lebih disarankan untuk implikasi di dalam klinis.

\section{SIMPULAN}

Intervensi teknik mobilization with movement lebih berpengaruh dibandingkan teknik peregangan dengan end range mobilization terhadap perbaikan keterbatasan lingkup gerak sendi.

\section{DAFTAR PUSTAKA}

Chen, Judy. 2012. Effectiveness of Passive Joint Mobilization for Shoulder Dysfunction: A Review of The Literature. Physiotherapy Department The Prince of Wales Hospital Sydney. 21st- Century. ISBN: 978-953-5104599.

Donatelli, R. 1997. Physical Therapy of the Shoulder. Third Edition, Churchill Livingston, United States of America.

Goyal, M. 2013. Combined Effect of End Range mobilization (ERM) and Mobilization with Movement (MWM) Techniques on Range 
Of Motion and Disability in Frozen Shoulder Patients: A Randomized Clinical Trial; Journal of Exercise Science and Physiotherapy. Journal of Exercise and Phsiotherapy. Vol. 9 No. 2, 74-82.

Hayes, K., Walton, J., Szomor, Z., Murrell, G. 2001. Reliability of five methods for assessing shoulder range of motion. Australian Journal of Physiotherapy. Volume 47. Number 289-294.

Hinton, Jame, 2013. The Effectiveness of endRange joint Mobilization For Patients With Adhesive Capsulitis. UCSF/SFSU Graduate Program in Physical Therapy. PT 209910.

Kapandji, I. A. 1989. The Physiology of the Joitns. Fifth Edition. Churchill Livingstone.

Kachingwe, A, F. 2008. Comparison of Manual Therapy Techniques with Therapeutic Exercise in the Treatment of Shoulder Impingement: A Randomized Controlled Pilot Clinical Trial. The Journal of Manual \& Manipulative Therapy. Volume 16 Number 4.

Kazmi, M., Devi, J., Yamin, Kumar. 2013. Comparative Study on the Efficacy of Maitland Technique (Grade IV) and Mulligan Technique, in the Treatment of Frozen Shoulder. Pakistan Journal of Rehabilitation. Volume 2. Issue 1.

Kelley, Martin, J. 2009. Frozen Shoulder; Evidence and a Proposed Model Guiding Rehabilitation. Journal of Orthopaedic and Sports Physical Therapy. Volume 39: Number 2.

Kisner, C., Colby, L. A. 2012. Therapeutic Exercise Foundation and Technique. Sixth Edition, F. A. Davis Company, Philadelphia.

Kumar, A., Aggarwal, A., Kumar, R., Ghosh Das, P. 2012. Effectiveness of Maitland Techniques in Idiopathic Shoulder $\begin{array}{lrr}\text { Adhesive } & \text { Capsulitis. } & \text { International } \\ \text { Scholarly } & \text { Research } & \text { Network } \\ \text { Rehabilitation, Volume 2012, page. } 8 .\end{array}$ Maitland, G., D. 199. Peripheral Maipulation. Third Edition, Butterworth \& Co Publishers, London.

Neviaser, A, S. 2010. Adhesive Capsulitis: A Review of Current Treatment. The American Journal of Sport medicine. First Version 38: 2346.

Page, P., Labbe, A. Adhesive Capsulitis: Use The Evidence to Integrate Interventions. North American Journal of Sport Physical therapy. V. 5(4), 266-273.

Russe, O. A., Gerhardt, J. J. 1975. International STFR Method of Measuring and Recording Joint Motion. Hans Huber Publishers Bern Stuttgart Vienna.

Schomacher, Jochen. 2014. Orthopedic Manual Therapy. Thieme Publisher Stuttgart. New York.

Teys, P. 2006. The Initial Effect of a Mulligan's Mobilization with Movement technique on Range Of Movement and Pressure Pain Threshold in Pain-Limited Shoulders. Science Direct. Volume: 13, 37-42.

Threlkel, Joseph. 1992. The Effects of manual Therapy on Connective Tissue. Physical Therapy Journal: APTA. Volume 72, number 12:893-902.

Vermeulen, H, M. 2000. End-Range Mobilization Techniques in Adhesive Capsulitis of the Shoulder Joint: A Multiple-Subject Case Report. Journal of the American Physical Therapy Association and de Fysiotherapeut. Volume 80:1204-1213.

Yang, J. 2007. Mobilization Techniques in Subjects With Frozen Shoulder Syndrome: Randomized Multiple- Treatment Trial. American Physical Therapy Association, Volume 87 Number 10 Physical Therapy $\mathrm{f}$ 1307. 